\title{
SECONDARY Aspergillus fumigatus INFECTION ASSOCIATED WITH COLOIDAL GOITER IN A BLACK-MASKED LOVEBIRD (Agapornis personata)
}

[Infecção secundária por Aspergillus fumigatus associada a bócio coloidal em Agaporne mascarado (Agapornis personata)]

\author{
Guilherme Augusto Marietto-Gonçalves ${ }^{1}$, Fabrizio Grandi ${ }^{2}$, Noeme Sousa Rocha ${ }^{2}$, Raphael Lucio \\ Andreatti Filho 1 \\ ${ }^{1}$ Laboratory of Avian Pathology, School of Veterinary Medicine and Animal Science, Univ. Estadual Paulista - UNESP. \\ Botucatu, Brazil. \\ ${ }^{2}$ Laboratory of Investigative and Comparative Pathology, School of Veterinary Medicine and Animal Science, Univ. Estadual \\ Paulista - UNESP. Botucatu, Brazil.
}

\begin{abstract}
Aspergillosis is caused by fungus of Aspergillus genus. Is a multifactorial secondary disease and occurs mainly to immunodeficiency. Goiter is the name to non-inflammatory and non-neoplasic thyroid growth which affecting the animal metabolism. In this report we describe a case of aspergillosis and colloidal goiter in a male Black-masked lovebird (Agapornis personata) diagnosed by post mortem exam. The bird was presented for examination due to severe respiratory signs. An initial palliative treatment was performed in order to relieve the symptoms. Despite this, the patient came to die without performing additional ancillary tests. On gross exam, a pulmonary nodule was observed from which we were able to isolate Aspergillus fumigatus on microbial culture. Histological assessment revealed pulmonary aspergilosis and colloid goiter. Based on histopathological and microbiological assessments we conclude that infection probably was secondary to colloid goiter.
\end{abstract}

Keywords: Agapornis personata, aspergillosis, goiter, avian pathology.

RESUMO - Aspergilose é uma doença causada por fungos do gênero Aspergillus. É uma doença secundária de caráter multifatorial e ocorre principalmente por imunodeficiência. O bócio é o nome dado ao crescimento nãoneoplásico e não-inflamatório da tireoide que afeta o metabolismo animal. O presente artigo descreve um caso de aspergilose e bócio coloidal em macho de Agaporne mascarado (Agapornis personata) diagnosticados por exame post mortem. A ave foi atendida com sintomatologia respiratória acentuada, sendo realizado um procedimento clínico inicial para aliviar os sintomas, porém a ave morreu sem que exames auxiliares fossem realizados. $\mathrm{Na}$ análise necroscópica foi encontrando a presença de um nódulo no pulmão e foi isolado Aspergillus fumigatus no exame microbiológico. A análise histológica confirmou o quadro de aspergilose e revelou também alterações tiroidianas compatíveis com bócio. Mediante os achados patológicos relacionou-se a ocorrência da infecção devido às alterações metabólicas causadas pelo quadro de bócio.

Palavras-Chave: Agapornis personata, aspergilose, bócio, patologia aviária.

\section{INTRODUCTION}

Aspergillosis is caused by fungi of the genus Aspergillus, with worldwide occurrence and describe in several avian orders (Keymer, 1982; Andreatti Filho, 2007). Is a multifactorial secondary disease and develops mainly in birds that live in environmental poorly cleaned in associate with immunodeficiency, intense stress, malnutrition, prolonged antibiotic and/or corticoid therapy (Bauk, 1994; Andreatti Filho, 2009).
Goiter is a name of non-inflammatory and nonneoplasic growth of thyroid gland and may be accompanied by hypothyroidism. Your origin may be caused by iodine deficiency, goitrogens substances or hereditary defects of thyroid hormones deficiency (Jones et al., 2000).

The present report describes a case of aspergillosis and colloidal goiter in a male Black-masked lovebird (Agapornis personata). That is the first relate in this specie.

Correspondence author. Email: gmarietto@ hotmail.com 


\section{CLINICAL REPORT}

A 1-year-old male Agapornis personata, Psittacidae family (Psittaciformes order), weighing 44g, was presented with 10-day history to apathy, hiperexy, emaciation, dyspnea, and respiratory clicking. Was administered nebulization aminophiline $(3 \mathrm{mg} / \mathrm{mL}$ sterile saline), $\mathrm{N}$-acetyl-L-cysteine $20 \%(22 \mathrm{mg} / \mathrm{mL}$ sterile water), lincomycin (50mg/kg, IM) and oxygen therapy (Carpenter, 2005; MariettoGonçalves, 2010) for respiratory stabilization and there was a clinical improvement. After initial treatment, aminophylline and N-acetyl-L-cysteine were administered every 3 hours. However the bird death after 10 hours without specific tests could be performed [i.e., hemogram and radiologic examination].
Externally, at necropsy, was observed muscle loss; in the right lung. In the visceral organs was observed in the ventral surface of distal portion, observed a larger caseous nodules with $0.4 \times 0.7 \mathrm{~cm}$ (Figure 1A), that then sectioned showed a green core content, occupying the internal inner of posterior thoracic air sac; pulmonary congestion; focal pneumonia; liver congestion, with small foci of pallor; and thyroid bilateral increase $(3 \mathrm{~mm}$ left/3.5 mm-right). No other gross lesions were identified. Sample of mass lung was plated for imprint in Sabouraud Dextrose agar and incubated at $36^{\circ} \mathrm{C}$ for 5 days. Lungs samples was also incubated in Brain-heart infusion at $36^{\circ} \mathrm{C}$ for 24 hours, plated in MacConkey and Blood agar for $36^{\circ} \mathrm{C}$ for 24 hours. Samples of liver, thyroid and lungs were fixed in $10 \%$ neutral-buffered formalin and routinely processed for histology.

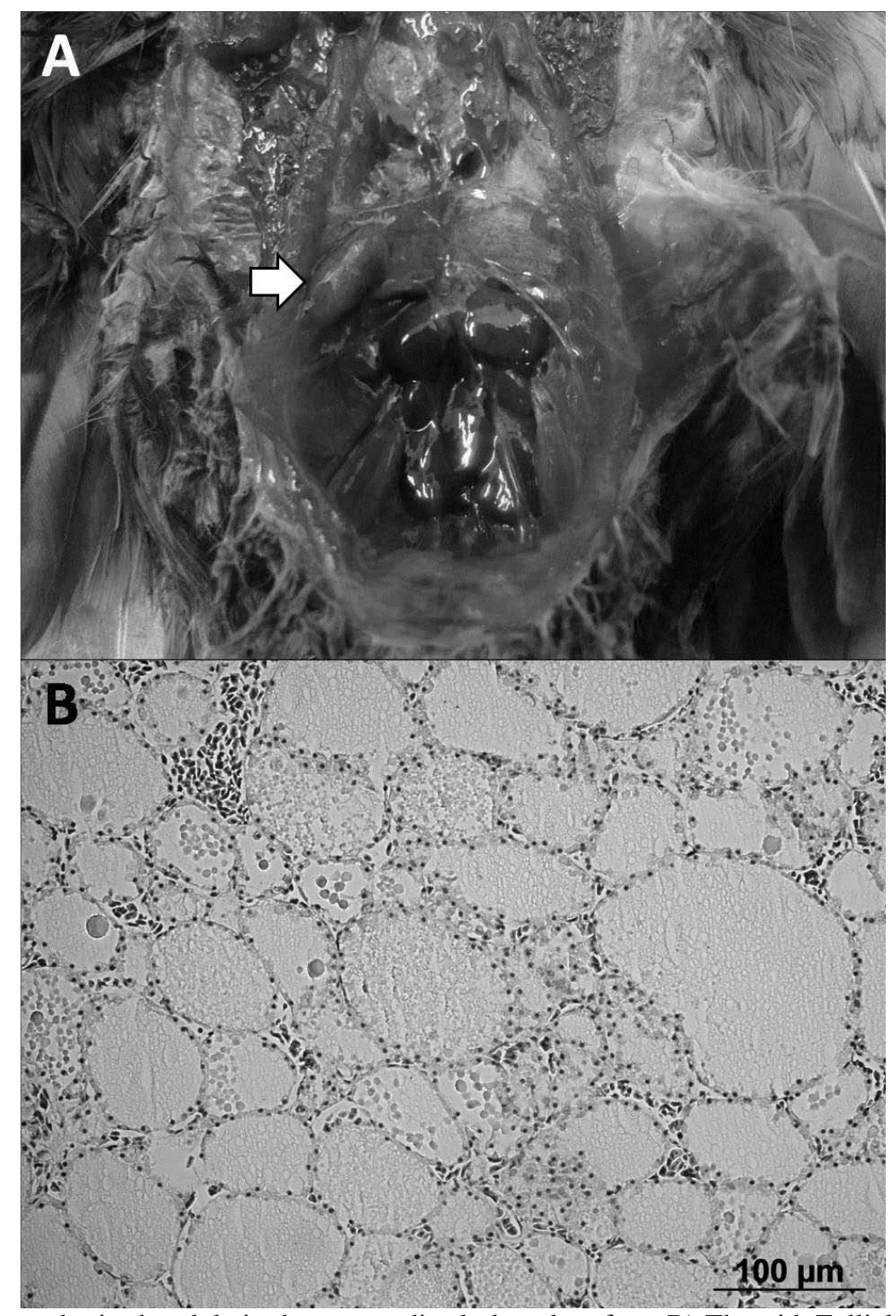

Figure 1. A) A firm and raised nodule in the ventro-distal pleural surface. B) Thyroid. Follicles are larger in size and with flattened lining cells and abundant colloid material (HE, 200x). 
In the bacteriologic evaluation were isolated only no-significative samples (Staphylococcus spp. nonhemolytic). In the mycologic evaluation was growth of blue-green-gray velvety colony compative to Aspergillus spp. (Figure 2A). With the lactophenol cotton blue staining (LCB) (15), hyphae morphological evaluation was performed, and Aspergillus fumigatus was identified (Figure 2B).

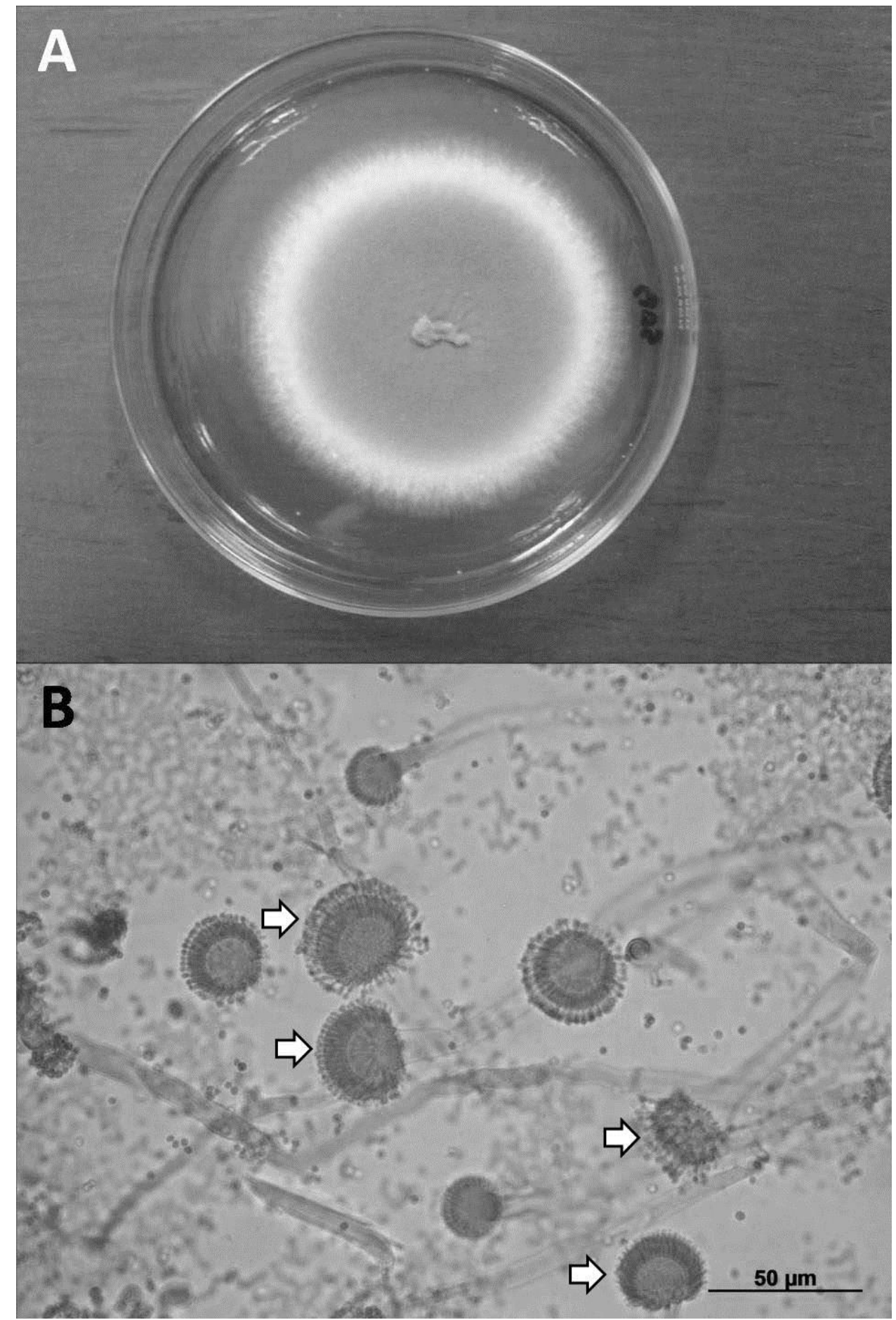

Figure 2. A) Sabourand Dextrose agar. A large greenish-gray Aspergillus spp. colony. B) Claviform conidiophores displaying terminal vesicle (LCB, 400x).

In the histologic examination, heterophilic infiltration foci, granulomas surround by giants cells in hematoxylin and eosin stain (HE) was observed in lung and pleura (Figure 3A), and fungus presence was identified within the granulomas in periodic acid-Schiff stain (PAS) in the lung (Figure 3B); colloidal lumen increase and interstitial tissue decrease in HE stain in the thyroid (Figure 1B); microscopic alterations no was observed in liver. 


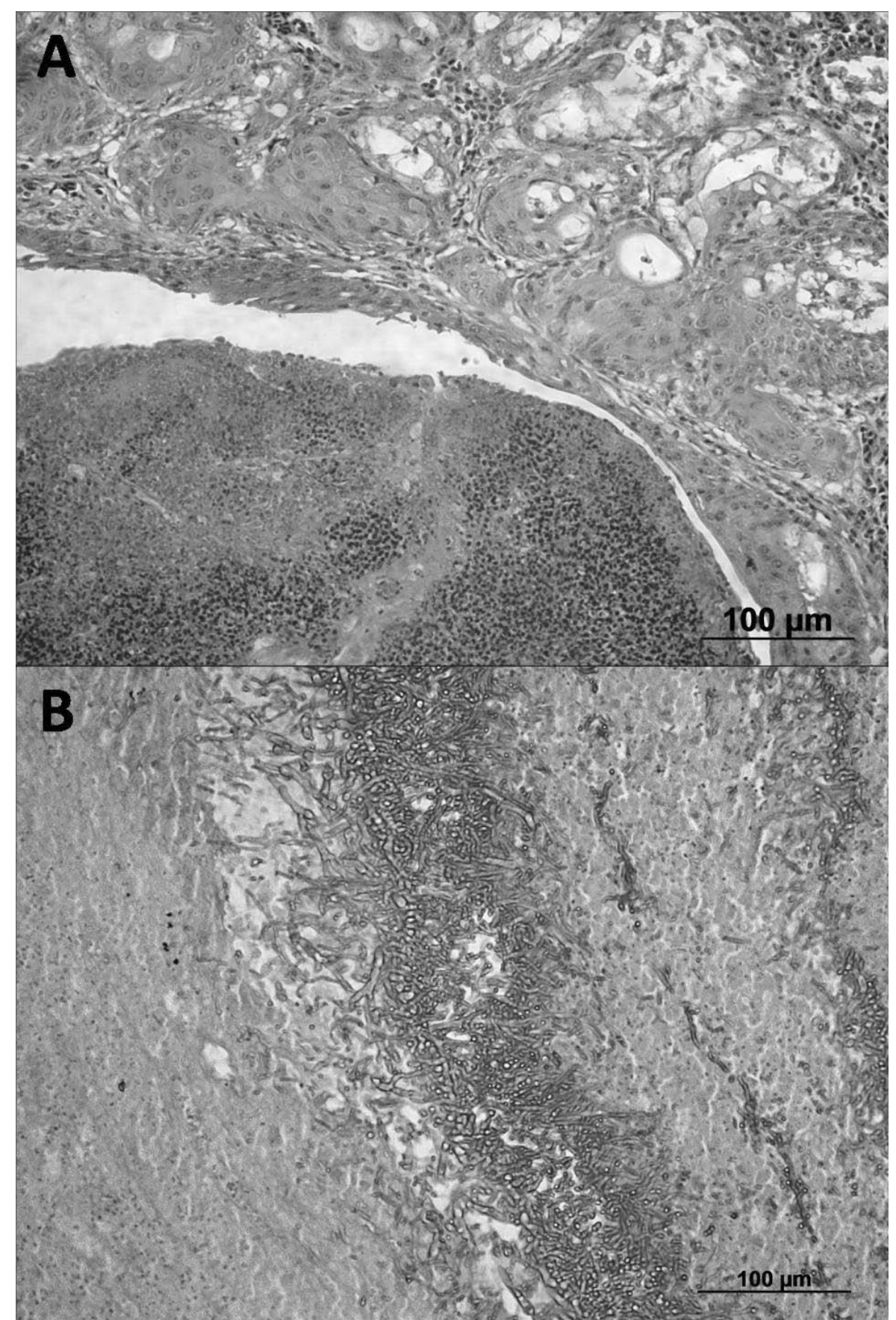

Figure 3. A) Pleural granuloma. Note caseous necrosis and several inflammatory cells in the periphery (HE, 200x). 3B) Pleural granuloma. Note several hyphae in the central portion (PAS, 200x).

\section{DISCUSSION}

Aspergillus fumigatus isolaments is common in birds and is the most frequently isolated from cases of avian aspergillosis. However, to medical importance consideration is important that to isolation is derived from lesions, because of the fact that Aspergillus can live a commensal in the respiratory tract birds exposed at environmental very contaminated (Keymer, 1982; Schimdt et al., 2003; Andreatti Filho, 2007). Aspergillus flavus, A. glaucus, A. oryzae, A. niger, and A. nidulans are also isolated from lesions in avians (Andreatti Filho, 2009).

Aspergillosis clinically is a respiratory disease, but can be a visceral our skin infection (MariettoGonçalves \& Andreatti Filho, 2007; Andreatti Filho, 2009). Clinical signs associated with aspergillosis of the respiratory tract may include dyspnea, depression, emaciation, open-mouthed breathing, stertors, pronounced excursions of the 
keel, tail "bobs" and respiratory distress after exercise are typical (Bauk, 1994).

The lesions caused by Aspergillus vary according to time of infection and may be focal our disseminated. Lungs and air sacs are primary affected organs, causing pneumonia and aerossaculitis, but trachea and syrinx can also be infected. Acute lesions present small white caseous nodules with surround hyperemic halo (in lungs) and tissue thickening (air sacs). Chronic lesions are marked by larger caseous nodules, can be caseous plate, yellowish-white mucoid exsudate presence, and in some cases are possible to find in organs and caseous nodules the presence to blue-green colonies (Andreatti Filho, 2009), as observed in this case.

In psittacines birds the occurrence of goiter was reported in Budgerigar (Melopsittacus undulates) (Wise, 1980), Cocktail (Nymphicus hollandicus) (Harms et al., 1994), Blue-fronted amazon parrot (Amazona aestiva) and White-eyed parakeet (Aratinga leucophthalma) (Marietto-Gonçalves et al., 2006). Goiter in animals occurs in many, and generally is caused by interferences in the synthesis of thyroid hormone resulting in thyroid gland continuous stimulation by Thyroid-stimulating hormone (TSH) from hypophysis. However, normally the serum levels of TSH do not increase (Jones et al., 2000).

Physiologically, the thyroxin $\left(\mathrm{T}_{4}\right)$, when secreted by thyroid gland inhibits the secretion of TSH and thus reducing the $\mathrm{T}_{4}$ production due inhibition of thyroid follicular cells. In diets where there is little iodine, basic compound to $\mathrm{T}_{4}$ production, occurs a break in the feedback system generating an increase in TSH production. Consequently, in an attempt to increase the $\mathrm{T}_{4}$ production occurs follicular cells proliferation characterized by unilateral our bilateral increased of the thyroid size (Steiner \& Davis, 1985; Marietto-Gonçalves et al., 2006).

Clinical signs of goiter vary according the degree of development. Birds can show lethargy, ruffled feathers, intolerance of temperature variation, and fertility decrease. As a consequence of anatomical compression in esophagus and trachea may have respiration and deglutition difficult, stertors, and emesis (Steiner \& Davis, 1985; Lothrop et al., 1986). In association with hypothyroidism there is loss feather and fat accumulation (Oglesbee, 1992; Harms et al., 1994), and in association with hyperthyroidism there is weight increase, hiperexy and bulky faeces (Lothrop et al., 1986).

Thyroid gland normally is large in necroscopic analysis, five to ten times greater than normal. Goiter in histological analysis present two stages: hyperplasic and colloidal involution. Hyperplasic stage is characterized by increase of interfollicular insterstitial tissue, cellular increase of the follicular epithelium, and colloidal lumen decrease. Colloidal stage is characterized by relative colloidal lumen increase in association to interstitial tissue decrease and thinning to follicular epithelium (Cotran \& Kumar, 2005), as observed in this case report.

Usually, for to ante-mortem aspergillosis diagnosis can use the techniques of cytology, and culture for samples obtained for endoscopy our biopsy (Bauk, 1994), and for goiter the ante-mortem diagnosis is obtained by clinical signs in association with radiographic analysis, serum dosage of $\mathrm{T}_{4}$ and $\mathrm{TSH}$, and glandular biopsy (Marietto-Gonçalves, 2010).

Because the metabolic alterations caused by goiter, we believe that aspergillosis occurred secondarily by immune response reducing, but clinically the goiter occurrence was oppressed by aspergillosis symptoms, justifying the diagnosis was obtained only after the death of the bird.

\section{REFERENCES}

Andreatti Filho R.L. 2007. Doenças fúngicas, p.236-245. In: Andreatti Filho R.L. (ed.). Saúde Aviária e Doenças. Roca, São Paulo.

Andreatti Filho R.L. 2009. Enfermidades Micóticas, p.805-818. In: Berchieri Júnior A, Silva E.N., Di Fábio J., Sesti L. \& Fagnani Zuazane M. A. (ed.). Doenças das Aves. Vol 2. Fundação APINCO de Ciência e Técnologia Avícolas, Campinas.

Bauk L. 1994. Mycoses, p.997-1006. In: Ritchie, B.W., Harrison G.J. \& Harrison L.R. (ed.). Avian Medicine: Principles and Application.. Wingers Publishing, Lake Worth.

Carpenter J.W. 2005. Exotic Animal Formulary. Vol. 3. Elsevier Saunders, St. Louis. 377 p.

Cotran R.S., Kumar V. \& Robbins S.L. 1994. Robbins: Pathologic Basis of Disease. Vol. 5. W.B. Saunders Company, Philadelphia. 889p.

Harms C.A., Hoskinson J.J., Bruyette D.S., Carpenter J.W., Galland J., Veatch J.K., Wilson S.C. \& Baier J.G. 1994. Development of an experimental model of hypothyroidism in Cockatiels (Nymphicus hollandicus). Am. J. Vet. Res. 55:399404.

Jones T.C., Hunt R.D. \& King N.W. 2000. Patologia Veterinária. Vol 6. Manole, São Paulo. 1415p.

Keymer I.F. 1982. Mycoses, p.599-605. In: Petrak, M. L. (ed.). Diseases of Cage and Aviary Birds. Vol. 2. Lea \& Fabiger, Philadelphia.

Lothrop C., Harrison G.J., Schultz D. \& Utteridge T. 1986. Miscellaneous diseases, p.525-536. In: Harrison G.J. \& Harrison L.R.(ed.). Clinical Avian Medicine and Surgery. W.B. Saunders Company, Philadelphia.

Marietto-Gonçalves G.A., Lima E.T., Sequeira J.L. \& Andreatti Filho R.L. 2006. Bócio colloidal em aves - Relato de Caso. Vet. Not. 12:71-74. 
Marietto-Gonçalves G.A. \& Andreatti Filho R.L. 2007. Aspergilose visceral causado por Aspergillus flavus em Marreca carolina (Aix sponsa). Acta Sci. Vet. 35: 253-256.

Marietto-Gonçalves G.A. 2010. Manual de Emergência em Aves. Medvet, São Paulo. 85p.

Oglesbee B.L. 1992. Hypothyroidism in a Scarlet macaw. J. Am. Vet. Med. Assoc. 201:1599-1601.
Richard J.L. \& Beneke E.S. 1989. Mycoses and Mycotoxicoses, p.70-76. In: Chairman H.G.P., Arp L.H., Domermuth C.H.

Schimdt R.E., Reavill D.R. \& Phalen D.N. 2003. Pathology of Pet and Aviary Birds. Blackwell Publishing, Ames. 240p.

Steiner C.V. and Davis R.B. 1985 Patologia de las Aves Enjauladas. Editorial Acribia, Zaragoza. 165p.

Wise R.D. 1980 Hyperplastic goiter in a Budgerigar. Vet. Med. Small Anim. Clin. 75:1013-1014 